\title{
Benzimidazolium Lead Halide Perovskites: Effects of Anion Substitution and Dimensionality on the Bandgap
}

\author{
Claudia Lermer, ${ }^{[a, b, c]}$ Sascha P. Harm, ${ }^{[b, c]}$ Susanne T. Birkhold, ${ }^{[d]}$ Julian A. Jaser, ${ }^{[a, b]}$ \\ Christopher M. Kutz, ${ }^{[b]}$ Peter Mayer, ${ }^{[b]}$ Lukas Schmidt-Mende, ${ }^{[d]}$ and \\ Bettina V. Lotsch*[a,b,c]
}

\author{
Dedicated to Professor Anthony K. Cheetham FRS on the Occasion of His 70th Birthday
}

\begin{abstract}
Keywords: Hybrid perovskites; Layered compounds; Organic-inorganic hybrid composites; Photoluminescence; Optical properties
\end{abstract}

\begin{abstract}
We present the synthesis and structural characterization of a series of benzimidazolium-based lead halide perovskites including $\left(\mathrm{C}_{7} \mathrm{H}_{7} \mathrm{~N}_{2}\right)_{2} \mathrm{PbCl}_{4},\left(\mathrm{C}_{7} \mathrm{H}_{7} \mathrm{~N}_{2}\right)_{2} \mathrm{PbBr}_{4},\left(\mathrm{C}_{7} \mathrm{H}_{7} \mathrm{~N}_{2}\right)_{2} \mathrm{PbI}_{4}$, and $\left(\mathrm{C}_{7} \mathrm{H}_{7} \mathrm{~N}_{2}\right) \mathrm{PbI}_{3}$, which serves as a platform to investigate the change in optical properties as a function of the halide and the dimensionality of the inorganic sublattice. The structural similarity of the layered systems with $A_{2} M X_{4}$ stoichiometry was verified by single-crystal X-ray diffraction and solid-state NMR spectroscopy. The optical properties were analyzed by absorption and photoluminescence (PL) measurements, confirming the
\end{abstract}

\section{Introduction}

Research in the field of 2D lead-halide hybrid perovskites is largely motivated by the great promise they hold as lowcost, chemically tunable absorber, transport and light-emitting materials in optoelectronic applications. The alternating arrangement of high dielectric lead halide layers and low dielectric organic layers in $2 \mathrm{D}$ hybrid perovskites gives rise to an inherent multiple-quantum-well structure, which results in the formation of excitons with large exciton binding energies in the metal halide sheets. ${ }^{[1-3]}$ The dielectric confinement effect entailing a sharp excitonic absorption peak can lead to interest-

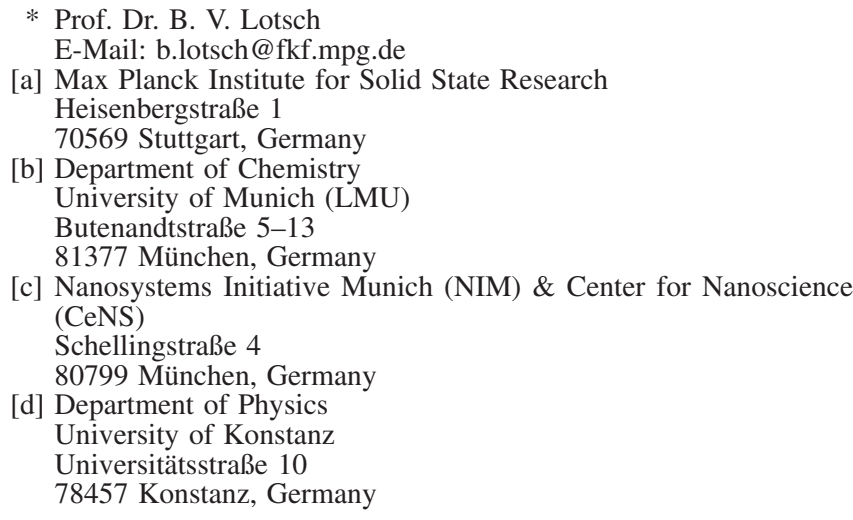

decrease in bandgap when exchanging the chloride with its higher homologues $\mathrm{Br}$ and $\mathrm{I}$. In addition, comparison of the layered compound $\left(\mathrm{C}_{7} \mathrm{H}_{7} \mathrm{~N}_{2}\right)_{2} \mathrm{PbI}_{4}$ with the known compound $\left(\mathrm{C}_{7} \mathrm{H}_{7} \mathrm{~N}_{2}\right) \mathrm{PbI}_{3}$ reveals an increase in bandgap on going from a $2 \mathrm{D}$ to a dimensionally reduced 1D topology. Besides, significant differences in the PL spectra of the halides are observed, which likely are due to recombination of self-trapped excitons stabilized through lattice distortions or permanent lattice defects in the compounds featuring broad PL emission bands.

ing optical properties including electroluminescence ${ }^{[4,5]}$ and strong room temperature photoluminescence, ${ }^{[6]}$ making applications in solid-state lighting conceivable as put forward by Karunadasa and co-workers. These authors reported 2D leadhalide hybrid perovskites featuring broadband white-light emission at room temperature with photoluminescence quantum efficiencies (PLQE) as high as $9 \% .{ }^{[7,8]}$ The hallmark of hybrid perovskites and related structures - their variability in structure and composition allowing for the exchange of the organic cation, the metal and the halide in hybrid perovskites makes this class of compounds a versatile platform for various applications in optoelectronics and beyond. ${ }^{[9]}$

Hybrid perovskites have been represented most notably by methylammonium lead iodide (MAPI), which features a high absorption coefficient and long ambipolar charge carrier diffusion lengths, thus rendering MAPI a promising solar cell absorber material. ${ }^{[10,11]}$ However, in the case of $2 \mathrm{D}$ perovskite materials with $n=1$ ( $n=$ number of corner-sharing octahedral layers in each inorganic block), the strong confinement of their excitons accompanied by short charge carrier diffusion lengths has hampered their application in photovoltaics so far. An interesting development is the incorporation of halides into the organic layer of several layered hybrid perovskites, ${ }^{[12,13]}$ which could serve as a handle to increase the dielectric constant in the organic layer which at the same time decreases the overall dielectric confinement. ${ }^{[13]}$ In principle, this modification could bring $2 \mathrm{D}$ hybrid perovskites back into the play when searching for future solar cell absorber materials. 
Herein we focus on the structural and optical investigation of the novel 2:1 benzimidazolium lead halide compounds $\left(\mathrm{C}_{7} \mathrm{H}_{7} \mathrm{~N}_{2}\right)_{2} \mathrm{PbCl}_{4},\left(\mathrm{C}_{7} \mathrm{H}_{7} \mathrm{~N}_{2}\right)_{2} \mathrm{PbBr}_{4}$, and $\left(\mathrm{C}_{7} \mathrm{H}_{7} \mathrm{~N}_{2}\right)_{2} \mathrm{PbI}_{4}$ featuring a $2 \mathrm{D}$ perovskite-type structure. This series of structurally related compounds enables us to systematically analyze the effect of exchanging the halide on the optical properties, while the crystal structure is maintained. In addition, the influence of the dimensionality of the lead halide sublattice on the optical bandgap is discussed by comparison with the compound $\left(\mathrm{C}_{7} \mathrm{H}_{7} \mathrm{~N}_{2}\right) \mathrm{PbI}_{3}$. The crystal structure and optical properties of $\left(\mathrm{C}_{7} \mathrm{H}_{7} \mathrm{~N}_{2}\right) \mathrm{PbI}_{3}$ were already reported by Wang et al., but studies on the bulk properties of the phase-pure material are still elusive. ${ }^{[14]}$ Note that the only benzimidazole lead halide compound described so far in the literature besides $\left(\mathrm{C}_{7} \mathrm{H}_{7} \mathrm{~N}_{2}\right) \mathrm{PbI}_{3}-$ $\mathrm{Pb}\left(\mathrm{C}_{7} \mathrm{H}_{6} \mathrm{~N}_{2}\right)_{2} \mathrm{Cl}_{4}$ - is a molecular coordination compound based on $\mathrm{Pb}^{\mathrm{IV}}$ and neutral benzimidazole, rather than an extended hybrid solid. ${ }^{[15]}$

\section{Results and Discussion}

\section{Synthesis of $\left(\mathrm{C}_{7} \mathrm{H}_{7} \mathrm{~N}_{2}\right)_{2} \mathrm{PbCl}_{4},\left(\mathrm{C}_{7} \mathrm{H}_{7} \mathrm{~N}_{2}\right)_{2} \mathrm{PbBr}_{4}$, $\left(\mathrm{C}_{7} \mathrm{H}_{7} \mathrm{~N}_{2}\right)_{2} \mathrm{PbI}_{4}$, and $\left(\mathrm{C}_{7} \mathrm{H}_{7} \mathrm{~N}_{2}\right) \mathrm{PbI}_{3}$}

Phase-pure $\quad\left(\mathrm{C}_{7} \mathrm{H}_{7} \mathrm{~N}_{2}\right)_{2} \mathrm{PbCl}_{4}, \quad\left(\mathrm{C}_{7} \mathrm{H}_{7} \mathrm{~N}_{2}\right)_{2} \mathrm{PbBr}_{4}, \quad$ and $\left(\mathrm{C}_{7} \mathrm{H}_{7} \mathrm{~N}_{2}\right) \mathrm{PbI}_{3}$ were obtained by the stoichiometric reaction of benzimidazole with $\mathrm{Pb} X_{2}(X=\mathrm{Cl}, \mathrm{Br}, \mathrm{I})$ in the respective hydrohalic acid. $\left(\mathrm{C}_{7} \mathrm{H}_{7} \mathrm{~N}_{2}\right)_{2} \mathrm{PbCl}_{4}$ was only obtained by evaporating the solvent in a nitrogen flow (Figure 1a). $\left(\mathrm{C}_{7} \mathrm{H}_{7} \mathrm{~N}_{2}\right)_{2} \mathrm{PbBr}_{4}$ and $\left(\mathrm{C}_{7} \mathrm{H}_{7} \mathrm{~N}_{2}\right) \mathrm{PbI}_{3}$ could also be obtained by adding ethyl acetate to the reaction mixture, which led to precipitation of the phase-pure product (Figure S1, Supporting Information). Besides, an alternative solvent-free synthesis procedure was explored for $\left(\mathrm{C}_{7} \mathrm{H}_{7} \mathrm{~N}_{2}\right)_{2} \mathrm{PbBr}_{4}$ and $\left(\mathrm{C}_{7} \mathrm{H}_{7} \mathrm{~N}_{2}\right) \mathrm{PbI}_{3}$. The precursors, benzimidazole and $\mathrm{Pb} X_{2}(X=\mathrm{Br}, \mathrm{I})$, were mixed and ground with a few drops of the respective hydrohalic acid. $\left(\mathrm{C}_{7} \mathrm{H}_{7} \mathrm{~N}_{2}\right) \mathrm{PbI}_{3}$ was obtained phase-pure, whereas $\left(\mathrm{C}_{7} \mathrm{H}_{7} \mathrm{~N}_{2}\right)_{2} \mathrm{PbBr}_{4}$ contained a small impurity (Figure S2, Supporting Information), which was further analyzed by energydispersive X-ray spectroscopy (EDX) and found to be a $\mathrm{Pb}$ rich phase displaying a needle-like morphology (Supporting Information S5).
We attempted to prepare phase-pure $\left(\mathrm{C}_{7} \mathrm{H}_{7} \mathrm{~N}_{2}\right)_{2} \mathrm{PbI}_{4}$ by solvent-free mechanochemical reactions of benzimidazolium iodide monohydrate, $\left(\mathrm{C}_{7} \mathrm{H}_{7} \mathrm{~N}_{2}\right) \mathrm{I} \cdot \mathrm{H}_{2} \mathrm{O}$, with $\mathrm{PbI}_{2}$, and of $\left(\mathrm{C}_{7} \mathrm{H}_{7} \mathrm{~N}_{2}\right) \mathrm{I} \cdot \mathrm{H}_{2} \mathrm{O}$ with $\left(\mathrm{C}_{7} \mathrm{H}_{7} \mathrm{~N}_{2}\right) \mathrm{PbI}_{3}$ using a mortar and pestle. Another attempt included the in situ protonation of benzimidazole with a few drops of HI while grinding the reagents benzimidazole and $\mathrm{PbI}_{2}$. We also attempted to synthesize the desired product in solution by reacting $\left(\mathrm{C}_{7} \mathrm{H}_{7} \mathrm{~N}_{2}\right) \mathrm{I}$ and $\mathrm{PbI}_{2}$ in dimethylformamide (DMF). In all cases, the main product $\left(\mathrm{C}_{7} \mathrm{H}_{7} \mathrm{~N}_{2}\right)_{2} \mathrm{PbI}_{4}$ was accompanied by $\left(\mathrm{C}_{7} \mathrm{H}_{7} \mathrm{~N}_{2}\right) \mathrm{PbI}_{3}$ as a side phase, as evidenced by powder X-ray diffraction (PXRD). In addition, $\mathrm{PbI}_{2}$ was detected as a second minor phase when used as a starting material in the synthesis. Therefore, we chose to focus on $\left(\mathrm{C}_{7} \mathrm{H}_{7} \mathrm{~N}_{2}\right) \cdot \cdot \mathrm{H}_{2} \mathrm{O}$ and $\left(\mathrm{C}_{7} \mathrm{H}_{7} \mathrm{~N}_{2}\right) \mathrm{PbI}_{3}$ as precursors, which were ground in a vibratory ball mill for $5 \mathrm{~d}$. Grinding the starting materials with a mortar gave similar results. The obtained bright red powder (Figure S4, Supporting Information) contains $\left(\mathrm{C}_{7} \mathrm{H}_{7} \mathrm{~N}_{2}\right)_{2} \mathrm{PbI}_{4}$ (red phase) and $\left(\mathrm{C}_{7} \mathrm{H}_{7} \mathrm{~N}_{2}\right) \mathrm{PbI}_{3}$ (yellow phase) in a ratio of 10 to 1 (hereafter BzImPbI4/3) as determined by Rietveld refinement of the collected PXRD data (Figure S3, Supporting Information). All details on the Rietveld analysis can be found in the Supporting Information S3. In addition, thermal stability data of $\left(\mathrm{C}_{7} \mathrm{H}_{7} \mathrm{~N}_{2}\right)_{2} \mathrm{PbCl}_{4}$, $\left(\mathrm{C}_{7} \mathrm{H}_{7} \mathrm{~N}_{2}\right)_{2} \mathrm{PbBr}_{4}$, and $\left(\mathrm{C}_{7} \mathrm{H}_{7} \mathrm{~N}_{2}\right) \mathrm{PbI}_{3}$ is reported in Supporting Information $\mathrm{S} 8$, revealing thermal stabilities up to $300{ }^{\circ} \mathrm{C}$ for the chloride and bromide and up to $350{ }^{\circ} \mathrm{C}$ for the iodide.

\section{Structural Investigation of $\left(\mathrm{C}_{7} \mathrm{H}_{7} \mathrm{~N}_{2}\right)_{2} \mathrm{PbCl}_{4}$, $\left(\mathrm{C}_{7} \mathrm{H}_{7} \mathrm{~N}_{2}\right)_{2} \mathrm{PbBr}_{4}$, and $\left(\mathrm{C}_{7} \mathrm{H}_{7} \mathrm{~N}_{2}\right)_{2} \mathrm{PbI}_{4}$}

The hybrid compounds $\left(\mathrm{C}_{7} \mathrm{H}_{7} \mathrm{~N}_{2}\right)_{2} \mathrm{PbCl}_{4},\left(\mathrm{C}_{7} \mathrm{H}_{7} \mathrm{~N}_{2}\right)_{2} \mathrm{PbBr}_{4}$, and $\left(\mathrm{C}_{7} \mathrm{H}_{7} \mathrm{~N}_{2}\right)_{2} \mathrm{PbI}_{4}$ exhibit layers of corner-sharing $\mathrm{PbX}$ octahedra separated by a double layer of protonated benzimidazolium cations, which protrude into the "cavities" formed by the $\mathrm{Pb} X_{6}$ octahedra with their imidazolium termini (Figure 2). The distance between the inorganic layers decreases from $14.48 \AA$ in $\left(\mathrm{C}_{7} \mathrm{H}_{7} \mathrm{~N}_{2}\right)_{2} \mathrm{PbCl}_{4}$ to $14.16 \AA$ in $\left(\mathrm{C}_{7} \mathrm{H}_{7} \mathrm{~N}_{2}\right)_{2} \mathrm{PbBr}_{4}$ and to $13.90 \AA$ in $\left(\mathrm{C}_{7} \mathrm{H}_{7} \mathrm{~N}_{2}\right)_{2} \mathrm{PbI}_{4}$, which seems counterintuitive at first sight given the increasing size of the halides. However, this trend can be rationalized by taking into account the increasing size of the cavities formed by the inorganic layers
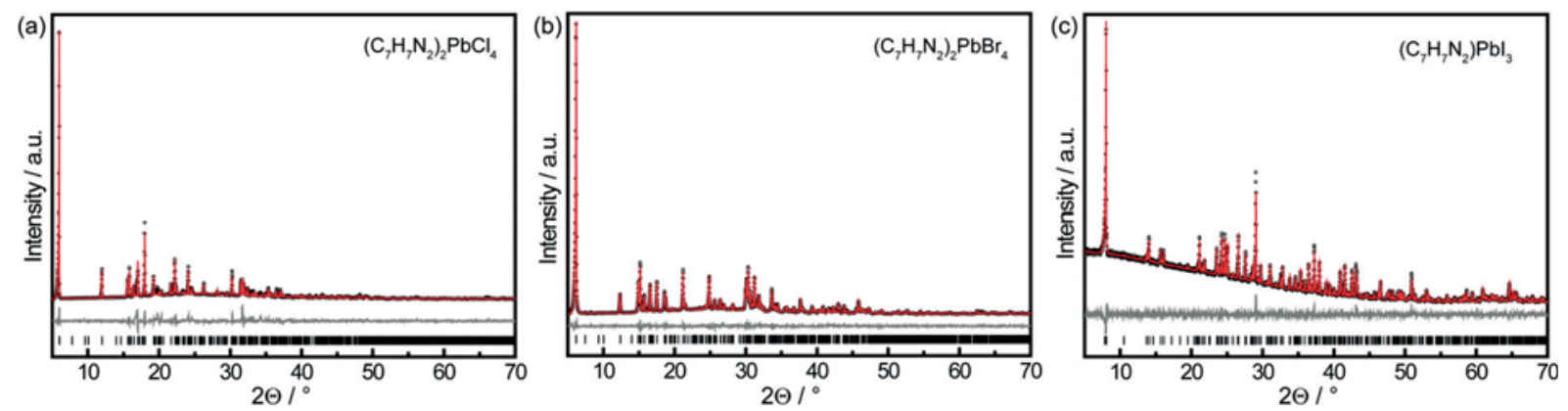

Figure 1. X-ray powder diffraction data and Rietveld refinements of $\left(\mathrm{C}_{7} \mathrm{H}_{7} \mathrm{~N}_{2}\right)_{2} \mathrm{PbCl}_{4}$ (a), $\left(\mathrm{C}_{7} \mathrm{H}_{7} \mathrm{~N}_{2}\right)_{2} \mathrm{PbBr}_{4}$ (b), and $\left(\mathrm{C}_{7} \mathrm{H}_{7} \mathrm{~N}_{2}\right) \mathrm{PbI}_{3}$ (c). The experimental patterns are represented by black open circles; the Rietveld profile fit (red solid line) and the difference profile (grey solid line) confirm phase purity. $\left(\mathrm{C}_{7} \mathrm{H}_{7} \mathrm{~N}_{2}\right)_{2} \mathrm{PbCl}_{4},\left(\mathrm{C}_{7} \mathrm{H}_{7} \mathrm{~N}_{2}\right)_{2} \mathrm{PbBr}_{4}$, and $\left(\mathrm{C}_{7} \mathrm{H}_{7} \mathrm{~N}_{2}\right) \mathrm{PbI}_{3}$ were obtained by evaporating the solvent under nitrogen flow from the precursor solution. 

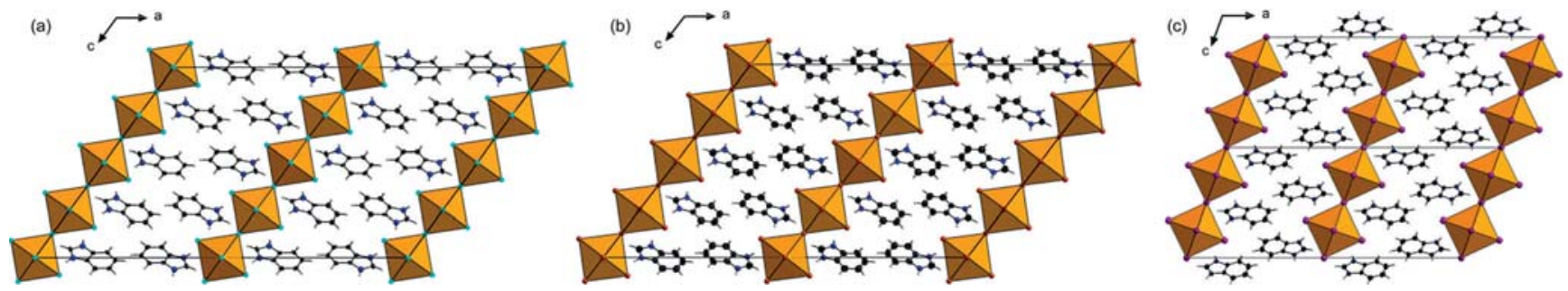

Figure 2. Crystal structures of $\left(\mathrm{C}_{7} \mathrm{H}_{7} \mathrm{~N}_{2}\right)_{2} \mathrm{PbCl}_{4}$ (a) and $\left(\mathrm{C}_{7} \mathrm{H}_{7} \mathrm{~N}_{2}\right)_{2} \mathrm{PbI}_{4}$ (c) measured at $100 \mathrm{~K}$ and $\left(\mathrm{C}_{7} \mathrm{H}_{7} \mathrm{~N}_{2}\right)_{2} \mathrm{PbBr}_{4}$ (b) measured at $173 \mathrm{~K}$ in projection along [010]. Thermal ellipsoids for carbon and nitrogen are drawn at the $70 \%$ probability level. $\mathrm{C}$ is displayed in black, $\mathrm{N}$ is blue, $\mathrm{H}$ is grey, $\mathrm{Pb}$ is orange, $\mathrm{Cl}$ is turquoise, $\mathrm{Br}$ is brown and $\mathrm{I}$ is purple. Cell edges are marked with black solid lines.

with increasing size of the respective halide ion from $\left(\mathrm{C}_{7} \mathrm{H}_{7} \mathrm{~N}_{2}\right)_{2} \mathrm{PbCl}_{4}$ to $\left(\mathrm{C}_{7} \mathrm{H}_{7} \mathrm{~N}_{2}\right)_{2} \mathrm{PbI}_{4}$. In this way, the organic and inorganic sublattices can interdigitate more closely such that the distance between the layers decreases.

The described orientation of the organic cations is most likely due to the formation of moderate to weak hydrogen bonds between the nitrogen atoms of the imidazolium moiety and the halide atoms of the $\mathrm{Pb} X_{6}$ octahedra; no $\pi-\pi$ interactions between the heteroaromatic units are observed (Figure 3, Tables SVI, SXI, SXVI, Supporting Information). The structure is stabilized further by ionic interactions between the negatively charged inorganic sublattice and the positively charged organic sublattice. All of the compounds discussed so far crystallize in the monoclinic space group $C 2 / c$. However, the arrangement of the benzimidazolium cations in $\left(\mathrm{C}_{7} \mathrm{H}_{7} \mathrm{~N}_{2}\right)_{2} \mathrm{PbI}_{4}$ differs from that in the isotypic compounds $\left(\mathrm{C}_{7} \mathrm{H}_{7} \mathrm{~N}_{2}\right)_{2} \mathrm{PbCl}_{4}$ and $\left(\mathrm{C}_{7} \mathrm{H}_{7} \mathrm{~N}_{2}\right)_{2} \mathrm{PbBr}_{4}$ as depicted in Figure 3. $\left(\mathrm{C}_{7} \mathrm{H}_{7} \mathrm{~N}_{2}\right)_{2} \mathrm{PbCl}_{4}$ and $\left(\mathrm{C}_{7} \mathrm{H}_{7} \mathrm{~N}_{2}\right)_{2} \mathrm{PbBr}_{4}$ feature two crystallographically distinct benzimidazolium cations: One comprising the atoms $\mathrm{N} 1$ and N3 (BzIm-N1N3) and the other one N2 and N4 (BzIm-N2N4). The cations alternate within the organic layer, whereby the $\pi$ planes of BzIm-N1N3 and BzIm-N2N4 comprise an angle of $7.3^{\circ}$ and $7.0^{\circ}$, respectively. The complete arrangement of benzimidazolium cations is obtained when applying a $c$ glide plane to the $\mathrm{A}$ and $\mathrm{A}^{\prime}$ layers, which results in the formation of the $\mathrm{B}$ and $\mathrm{B}^{\prime}$ layers, respectively (Figure $3 \mathrm{a}$ ). In contrast, the "zigzag" pattern in $\left(\mathrm{C}_{7} \mathrm{H}_{7} \mathrm{~N}_{2}\right)_{2} \mathrm{PbI}_{4}$ containing only one unique benzimidazolium cation arises from applying the $c$ glide plane to the A layer. Consequently, the lattice parameter in $c$ direction is halved compared to the chloride and bromide version (Figure 3). The observed distortion of the $\mathrm{Pb} X_{6}$ octahedra, which is similar for all compounds and becomes primarily apparent in the $X-\mathrm{Pb}-X$ bond angles [82.83(3)-97.17(3) ${ }^{\circ}$ in $\left(\mathrm{C}_{7} \mathrm{H}_{7} \mathrm{~N}_{2}\right)_{2} \mathrm{PbCl}_{4}, 83.523(6)-96.477(6)^{\circ}$ in $\left(\mathrm{C}_{7} \mathrm{H}_{7} \mathrm{~N}_{2}\right)_{2} \mathrm{PbBr}_{4}$, and $83.928(4)-96.072(4)^{\circ}$ in $\left.\left(\mathrm{C}_{7} \mathrm{H}_{7} \mathrm{~N}_{2}\right)_{2} \mathrm{PbI}_{4}\right]$ is likely connected to the benzimidazolium cations pushing into the cavities of the inorganic lattice and the formation of hydrogen bonds between the organic cations and the $\mathrm{Pb} X_{6}$ octahedra's halide atoms as discussed above. Another source of the observed lattice distortion may be the stereochemically active $6 \mathrm{~s} \mathrm{~Pb}$ lone pair as observed for other layered lead-based hybrid perovskites. ${ }^{[16]}$ However, electronic structure calculations would be needed to further analyze the origin of the observed distortion.
Crystallographic data and details of the structure refinements are shown in Tables SI-SV, SVII-SX, and SXII-SXV (Supporting Information).

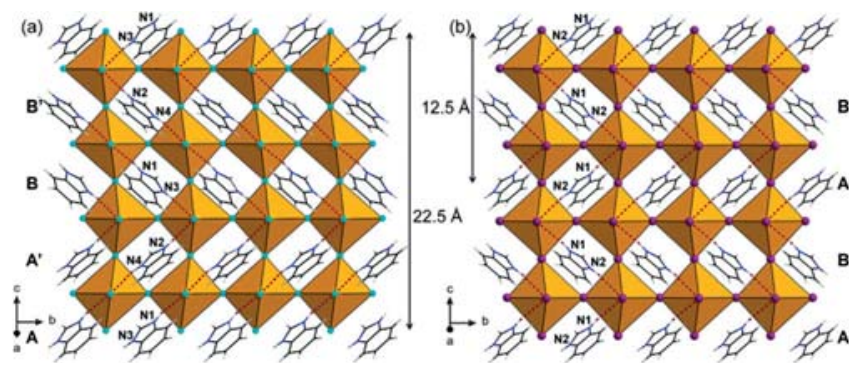

Figure 3. Crystal structures of $\left(\mathrm{C}_{7} \mathrm{H}_{7} \mathrm{~N}_{2}\right)_{2} \mathrm{PbCl}_{4}$ (a) and $\left(\mathrm{C}_{7} \mathrm{H}_{7} \mathrm{~N}_{2}\right)_{2} \mathrm{PbI}_{4}$ (b), view onto the (100) plane. The length of the respective $c$ axis is emphasized. Hydrogen bonds are marked with red dashed lines. Nitrogen atoms are labeled exemplarily. $\mathrm{C}$ is displayed in black, $\mathrm{N}$ is blue, $\mathrm{H}$ is grey, $\mathrm{Pb}$ is orange, $\mathrm{Cl}$ is turquoise, and $\mathrm{I}$ is purple.

\section{Structural Investigation of $\left(\mathrm{C}_{7} \mathrm{H}_{7} \mathrm{~N}_{2}\right) \mathrm{PbI}_{3}$}

Since the structure of $\left(\mathrm{C}_{7} \mathrm{H}_{7} \mathrm{~N}_{2}\right) \mathrm{PbI}_{3}$ was already determined by Wang et al., ${ }^{[14]}$ it is only described briefly here for completeness. The hybrid compound $\left(\mathrm{C}_{7} \mathrm{H}_{7} \mathrm{~N}_{2}\right) \mathrm{PbI}_{3}$ exhibits $P 2_{1} 2_{1} 2_{1}$ symmetry and features double chains of edge-sharing $\mathrm{PbI}_{6}$ octahedra, which are surrounded by benzimidazolium cations arranged in stacks of two (Figure 4a); the structure can thus be considered as quasi one-dimensional. The benzimidazolium cations are parallel to each other when belonging to the same stack but tilted by $89.8^{\circ}$ with respect to the cations of the associated stack (Figure 4b). Besides apparent ionic interactions between the negatively charged inorganic layer and the protonated benzimidazole cations, weak hydrogen bonds $(\mathrm{N}-\mathrm{H} \cdots \mathrm{I}=3.537$ and $3.638 \AA$ ) between the benzimidazolium $\mathrm{N}$ atoms and the $\mathrm{I} 3$ atoms of the inorganic sublattice could be identified as the predominant interactions in $\left(\mathrm{C}_{7} \mathrm{H}_{7} \mathrm{~N}_{2}\right) \mathrm{PbI}_{3}$. Also, a distortion of the $\mathrm{PbI}_{6}$ octahedra is apparent which is likely due to structural features, specifically the formation of hydrogen bonds, or possible $\mathrm{Pb}$ lone pair effects as mentioned above (Figure 4c, Table XXII). Crystallographic data and details of the structure refinements are shown in Tables SXVIISXXI (Supporting Information). 


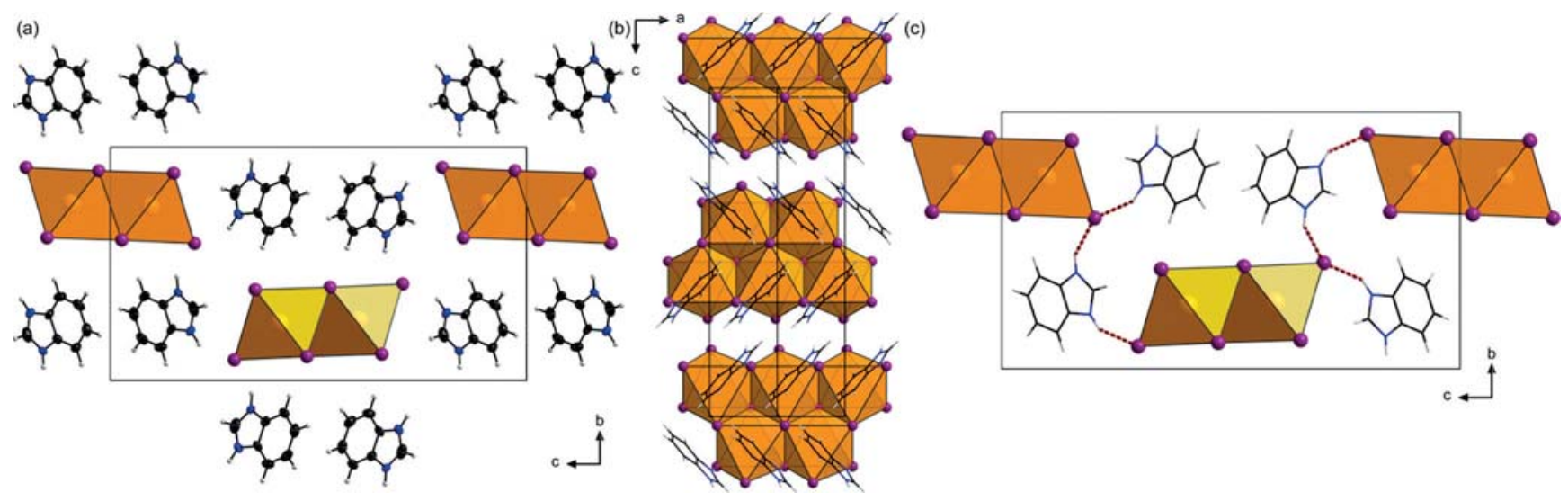

Figure 4. Crystal structure of $\left(\mathrm{C}_{7} \mathrm{H}_{7} \mathrm{~N}_{2}\right) \mathrm{PbI}_{3}$ in projection along [100] (a, c), and [010] (b). Thermal ellipsoids for carbon and nitrogen are drawn at the $70 \%$ probability level. Hydrogen bonds are marked with red dashed lines. $\mathrm{C}$ is displayed in black, $\mathrm{N}$ is blue, $\mathrm{H}$ is grey, $\mathrm{Pb}$ is orange, and I is purple. Cell edges are marked with black solid lines.

\section{Solid-state NMR Spectroscopy}

${ }^{1} \mathrm{H},{ }^{13} \mathrm{C}$, and ${ }^{15} \mathrm{~N}$ solid-state NMR spectroscopy was applied as a tool to access the local structure of the organic sublattice and to confirm the integrity of the benzimidazolium cation in $\left(\mathrm{C}_{7} \mathrm{H}_{7} \mathrm{~N}_{2}\right)_{2} \mathrm{PbCl}_{4},\left(\mathrm{C}_{7} \mathrm{H}_{7} \mathrm{~N}_{2}\right)_{2} \mathrm{PbBr}_{4}$, and $\left(\mathrm{C}_{7} \mathrm{H}_{7} \mathrm{~N}_{2}\right) \mathrm{PbI}_{3}$ (Figure 5). The ${ }^{1} \mathrm{H}$ spectra of the chloride and the bromide compound show three distinguishable signals at $13.18(\mathrm{~N}-\mathrm{H}), 9.21$ $\left(\mathrm{C}_{2}-\mathrm{H}\right)$ and $6.86\left(\mathrm{C}_{4 / 7,5 / 6}-\mathrm{H}\right) \mathrm{ppm}$ and at $12.66(\mathrm{~N}-\mathrm{H}), 9.04$ $\left(\mathrm{C}_{2}-\mathrm{H}\right)$ and $7.54\left(\mathrm{C}_{4 / 7,5 / 6}-\mathrm{H}\right) \mathrm{ppm}$, respectively. In contrast, only two signals at $11.18(\mathrm{~N}-\mathrm{H})$ and $7.89\left(\mathrm{C}_{2,4 / 7,5 / 6}-\mathrm{H}\right) \mathrm{ppm}$ are resolved for $\left(\mathrm{C}_{7} \mathrm{H}_{7} \mathrm{~N}_{2}\right) \mathrm{PbI}_{3}$. The differences in local structure and hydrogen bonding between the isotypic compounds $\left(\mathrm{C}_{7} \mathrm{H}_{7} \mathrm{~N}_{2}\right)_{2} \mathrm{PbCl}_{4}$ and $\left(\mathrm{C}_{7} \mathrm{H}_{7} \mathrm{~N}_{2}\right)_{2} \mathrm{PbBr}_{4}$ and the $1 \mathrm{D}$ compound $\left(\mathrm{C}_{7} \mathrm{H}_{7} \mathrm{~N}_{2}\right) \mathrm{PbI}_{3}$ are reflected in differences in the ${ }^{13} \mathrm{C}$ chemical shifts by as much as $4.5 \mathrm{ppm}$. The chemical shifts are in good agreement with a study by Pugmire et al., who investigated molecular benzimidazole hydrochloride in a saturated aqueous solution. ${ }^{[17]}$ The ${ }^{13} \mathrm{C}$ spectra of the investigated compounds show four distinct signals, in line with the mirror plane intersecting the benzimidazolium cation along its longest axis. The protonation of benzimidazole becomes also obvious in the observed upfield shifts for $\mathrm{C}_{4}$ and $\mathrm{C}_{9}$ as compared to neutral benzimidazole. ${ }^{[18]}$ Notably, $\mathrm{C}_{2}$ is downfield shifted on going from the iodide to the bromide to the chloride, which is consis- tent with increasingly strong hydrogen-bonding interactions along this series, leading to a deshielding of the carbon neighboring the protonated nitrogen atoms. The splitting of the $\mathrm{C}_{5 / 6}$ signal visible for $\left(\mathrm{C}_{7} \mathrm{H}_{7} \mathrm{~N}_{2}\right)_{2} \mathrm{PbBr}_{4}$ is likely due to the presence of the two crystallographically distinct benzimidazolium cations, whose chemical environments are so similar that all other signals coalesce in $\left(\mathrm{C}_{7} \mathrm{H}_{7} \mathrm{~N}_{2}\right)_{2} \mathrm{PbBr}_{4}$ and $\left(\mathrm{C}_{7} \mathrm{H}_{7} \mathrm{~N}_{2}\right)_{2} \mathrm{PbCl}_{4}$. The ${ }^{15} \mathrm{~N}$ spectra show only one signal between -221.15 and $-222.39 \mathrm{ppm}$, which confirms the presence of two chemically equivalent protonated imidazolium nitrogen atoms as well as the similar local environments of the crystallographically different benzimidazolium units. ${ }^{[18]}$ The assignment of the signals in the ${ }^{13} \mathrm{C}$ and ${ }^{15} \mathrm{~N}$ spectra is displayed in detail in the Supporting Information S6.

\section{Optical Properties}

The optical properties of $\left(\mathrm{C}_{7} \mathrm{H}_{7} \mathrm{~N}_{2}\right)_{2} \mathrm{PbCl}_{4},\left(\mathrm{C}_{7} \mathrm{H}_{7} \mathrm{~N}_{2}\right)_{2} \mathrm{PbBr}_{4}$, $\left(\mathrm{C}_{7} \mathrm{H}_{7} \mathrm{~N}_{2}\right) \mathrm{PbI}_{3}$, and BzImPbI4/3 [containing $\left(\mathrm{C}_{7} \mathrm{H}_{7} \mathrm{~N}_{2}\right)_{2} \mathrm{PbI}_{4}$ and $\left(\mathrm{C}_{7} \mathrm{H}_{7} \mathrm{~N}_{2}\right) \mathrm{PbI}_{3}$ in a ratio of 10 to 1 , see above], were investigated by absorbance and photoluminescence (PL) measurements, as presented in Figure 6. The bandgaps $E_{\mathrm{g}}$, as determined by Tauc plots (see S7, Supporting Information) decrease on going from the chloride $\left(E_{\mathrm{g}}=3.08 \mathrm{eV}\right)$ to the bromide
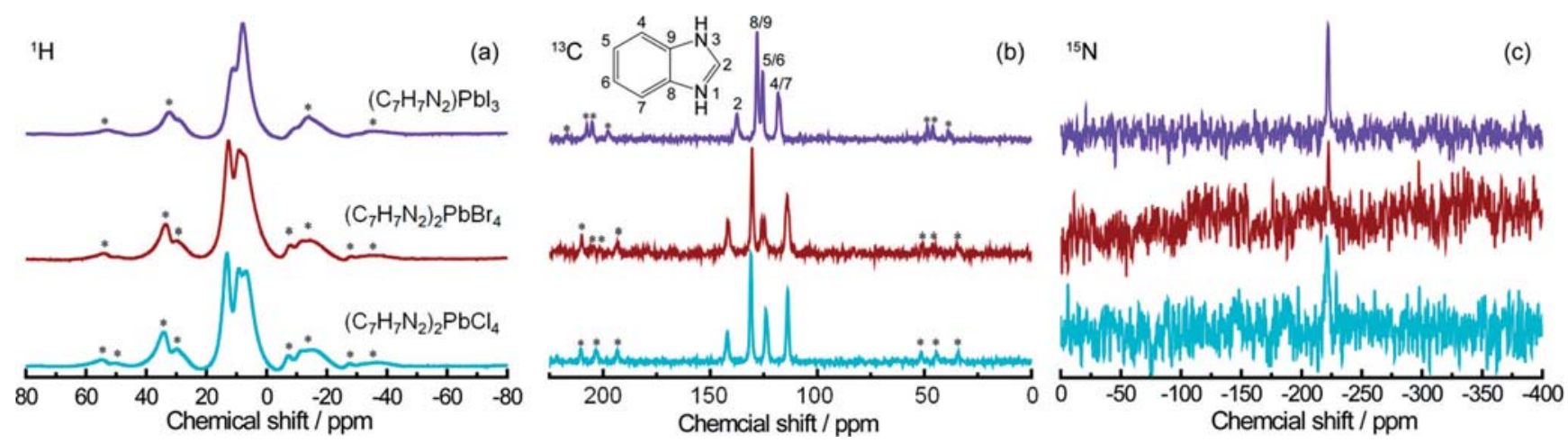

Figure 5. ${ }^{1} \mathrm{H}$ MAS (a), ${ }^{13} \mathrm{C}$ CP MAS (b) and ${ }^{15} \mathrm{~N}$ CP MAS (c) solid-state NMR spectra of $\left(\mathrm{C}_{7} \mathrm{H}_{7} \mathrm{~N}_{2}\right)_{2} \mathrm{PbCl}_{4}(\mathrm{cyan}),\left(\mathrm{C}_{7} \mathrm{H}_{7} \mathrm{~N}_{2}\right)_{2} \mathrm{PbBr}_{4}$ (brown) and $\left(\mathrm{C}_{7} \mathrm{H}_{7} \mathrm{~N}_{2}\right) \mathrm{PbI}_{3}$ (purple). Spinning side bands are marked with asterisks. 
$\left(E_{\mathrm{g}}=2.60 \mathrm{eV}\right)$ to the iodide $\left(E_{\mathrm{g}}=1.99 \mathrm{eV}\right)$, which becomes clearly visible in the color change from white to yellow to red for $\left(\mathrm{C}_{7} \mathrm{H}_{7} \mathrm{~N}_{2}\right)_{2} \mathrm{PbCl}_{4},\left(\mathrm{C}_{7} \mathrm{H}_{7} \mathrm{~N}_{2}\right)_{2} \mathrm{PbBr}_{4}$, and $\left(\mathrm{C}_{7} \mathrm{H}_{7} \mathrm{~N}_{2}\right)_{2} \mathrm{PbI}_{4}$, respectively (Figure $7 \mathrm{a}, \mathrm{b}$, and $\mathrm{d}$ ).

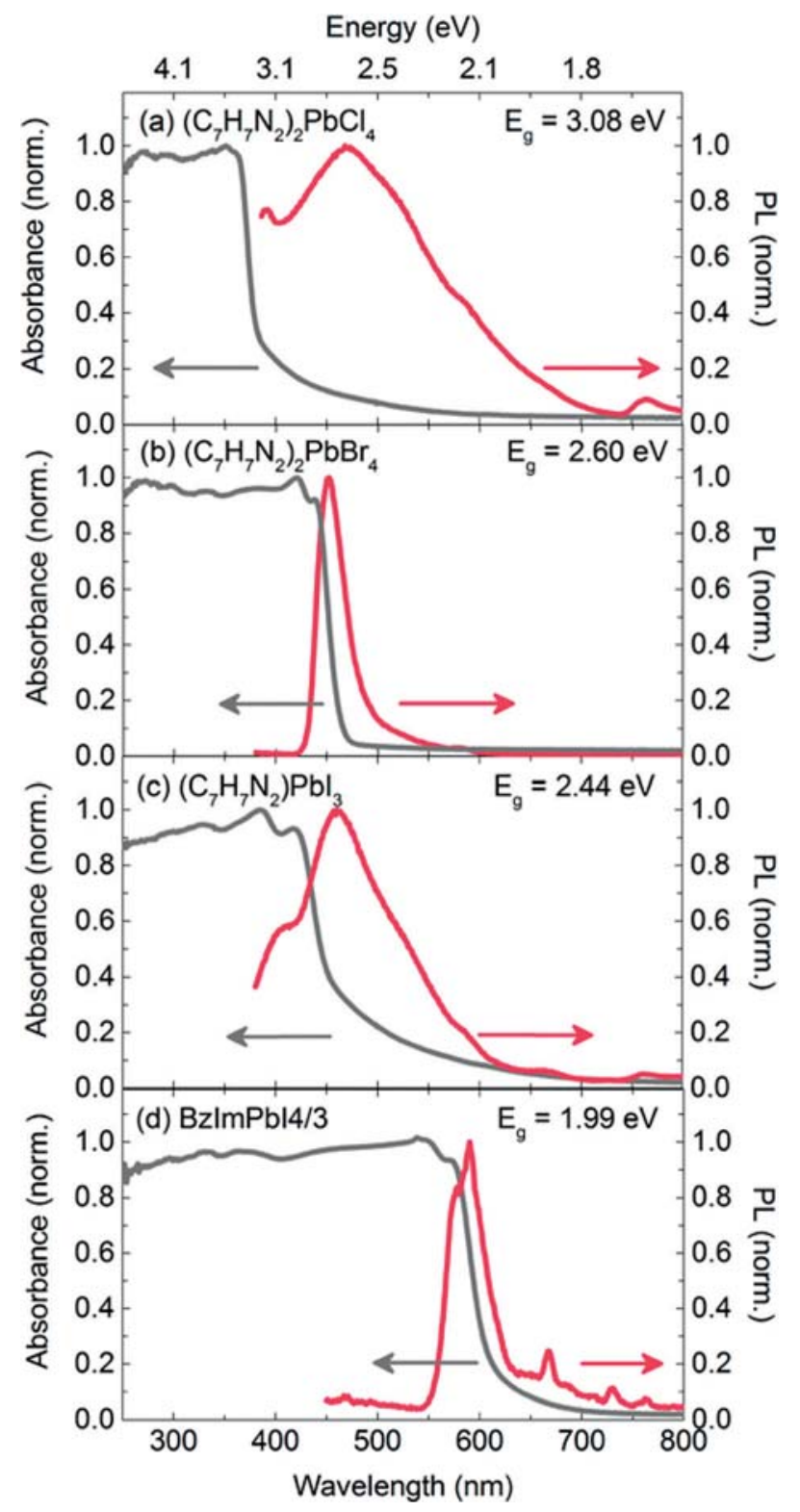

Figure 6. Absorbance (grey line) and photoluminescence spectra (red line, $\left.\lambda_{\text {excitation }}=350 \mathrm{~nm}\right)$ of $\left(\mathrm{C}_{7} \mathrm{H}_{7} \mathrm{~N}_{2}\right)_{2} \mathrm{PbCl}_{4}$ (a), $\left(\mathrm{C}_{7} \mathrm{H}_{7} \mathrm{~N}_{2}\right)_{2} \mathrm{PbBr}_{4}$ (b), $\left(\mathrm{C}_{7} \mathrm{H}_{7} \mathrm{~N}_{2}\right) \mathrm{PbI}_{3}$ (c), and BzImPbI4/3 (d) at room temperature. Bandgaps $E_{\mathrm{g}}$ are extracted from Tauc plots presented in S7 (Supporting Information).
Bandgap tuning of metal halide perovskites has been widely investigated for solar cell applications of 3D perovskites, where variations in the halide as in $\mathrm{CH}_{3} \mathrm{NH}_{3} \mathrm{~Pb}\left(\mathrm{I}_{1-x} \mathrm{Br}_{x}\right)_{3},{ }^{[19,20]}$ or in the organic cation ${ }^{[21]}$ lead to changes in the bandgap, which were found to correlate with changes in the metal-halide bond length. Besides the lattice parameters, the bandgap of perovskites is also influenced by the compound's dimensionality as can be seen for the iodide based compounds in Figure 6c and $\mathrm{d}$. A decrease in the dimensionality from 2D (in BzImPbI4/3) to $1 \mathrm{D}$ [in $\left(\mathrm{C}_{7} \mathrm{H}_{7} \mathrm{~N}_{2}\right) \mathrm{PbI}_{3}$ ] increases the bandgap $E_{\mathrm{g}}$ from $1.99 \mathrm{eV}$ to $2.44 \mathrm{eV}$ and is accompanied by a color change from red to yellow (Figure 7c, d). The bandgap of $\left(\mathrm{C}_{7} \mathrm{H}_{7} \mathrm{~N}_{2}\right) \mathrm{PbI}_{3}$ has been reported by Wang et al. to be $2.76 \mathrm{eV}$, which may point to the presence of impurity phases since the precursors for $\left(\mathrm{C}_{7} \mathrm{H}_{7} \mathrm{~N}_{2}\right) \mathrm{PbI}_{3}$, where reacted at off-stoichiometric ratios by Wang et al. ${ }^{[14]}$ The impact of halide exchange and dimensionality on the bandgap energy can also be seen by comparison of the herein presented perovskite compounds to the 3D perovskites $\left(\mathrm{CH}_{3} \mathrm{NH}_{3}\right) \mathrm{PbCl}_{3},\left(\mathrm{CH}_{3} \mathrm{NH}_{3}\right) \mathrm{PbBr}_{3}$, and $\left(\mathrm{CH}_{3} \mathrm{NH}_{3}\right) \mathrm{PbI}_{3}$ with bandgaps of $2.88 \mathrm{eV}, 2.2 \mathrm{eV}$, and $1.5 \mathrm{eV}$, respectively. ${ }^{[22,23]}$

Concerning the PL spectra, striking variations in the spectral width occur for the different structures. For both $\left(\mathrm{C}_{7} \mathrm{H}_{7} \mathrm{~N}_{2}\right)_{2} \mathrm{PbBr}_{4}$ and BzImPbI4/3, a relatively narrow PL emission coincides well with the absorbance edge. Yet, additional PL emission peaks appear for BzImPbI4/3, which can be related to impurity states, as the sample contains about $10 \%$ $\left(\mathrm{C}_{7} \mathrm{H}_{7} \mathrm{~N}_{2}\right) \mathrm{PbI}_{3}$ impurities. In general, photo-excited states relax to the energetically lowest accessible states before recombination into the ground state, which gives rise to PL emission. The absent emission of $\left(\mathrm{C}_{7} \mathrm{H}_{7} \mathrm{~N}_{2}\right) \mathrm{PbI}_{3}$ at $460 \mathrm{~nm}$ in the PL of BzImPbI4/3 might be due to a reabsorption by $\left(\mathrm{C}_{7} \mathrm{H}_{7} \mathrm{~N}_{2}\right)_{2} \mathrm{PbI}_{4}$ components. However, both samples have minor PL signals at $580 \mathrm{~nm}$ and $668 \mathrm{~nm}$, which indicates emission of $\left(\mathrm{C}_{7} \mathrm{H}_{7} \mathrm{~N}_{2}\right) \mathrm{PbI}_{3}$ states within BzImPbI4/3, likely due to a hindered charge transfer from these low energy states into $\left(\mathrm{C}_{7} \mathrm{H}_{7} \mathrm{~N}_{2}\right)_{2} \mathrm{PbI}_{4}$. In contrast to the sharp band-to-band transition of $\left(\mathrm{C}_{7} \mathrm{H}_{7} \mathrm{~N}_{2}\right)_{2} \mathrm{PbBr}_{4}$ and BzImPbI4/3, the PL spectra of $\left(\mathrm{C}_{7} \mathrm{H}_{7} \mathrm{~N}_{2}\right)_{2} \mathrm{PbCl}_{4}$ and $\left(\mathrm{C}_{7} \mathrm{H}_{7} \mathrm{~N}_{2}\right) \mathrm{PbI}_{3}$ are characterized by a broad and strongly Stokes shifted PL emission that includes multiple emission peaks. Likewise, the absorbance spectra of $\left(\mathrm{C}_{7} \mathrm{H}_{7} \mathrm{~N}_{2}\right)_{2} \mathrm{PbCl}_{4}$ and $\left(\mathrm{C}_{7} \mathrm{H}_{7} \mathrm{~N}_{2}\right) \mathrm{PbI}_{3}$ also possess significant intensity below their absorbance edges. The origin of this broad, white light PL emission for layered organic-inorganic perovskites has been identified by Dohner et al. to originate from self-trapped excitons that strongly couple to a deformable lattice and structural distortions, driven by strong electron- (a)

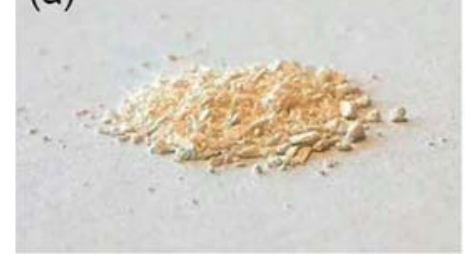

(b)

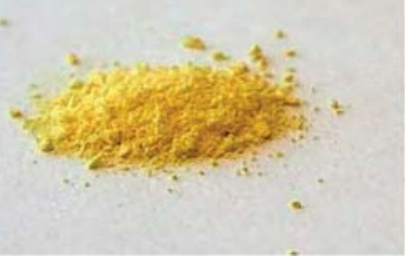

(c)

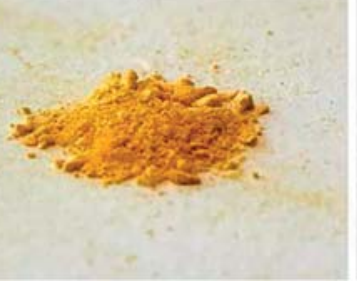

(d)

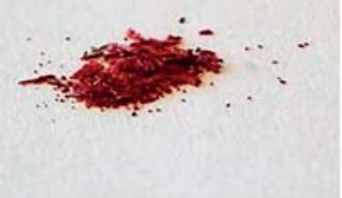

Figure 7. Photographs of $\left(\mathrm{C}_{7} \mathrm{H}_{7} \mathrm{~N}_{2}\right)_{2} \mathrm{PbCl}_{4}(\mathrm{a}),\left(\mathrm{C}_{7} \mathrm{H}_{7} \mathrm{~N}_{2}\right)_{2} \mathrm{PbBr}_{4}$ (b), and $\left(\mathrm{C}_{7} \mathrm{H}_{7} \mathrm{~N}_{2}\right) \mathrm{PbI}_{3}$ powder (c) and of $\left(\mathrm{C}_{7} \mathrm{H}_{7} \mathrm{~N}_{2}\right)_{2} \mathrm{PbI}_{4}$ crystals (d). 
phonon coupling. ${ }^{[8]}$ The transient, photo-induced formation of these self-trapped excitons has been observed to occur on a femtosecond (fs) - timescale and its multicomponent nature has been confirmed by temperature dependent and time-resolved PL measurements. ${ }^{[24-26]}$ Note that all compounds studied here show similar levels of distortions of the inorganic sublattice, which is why the observed differences in the PL emission may result from different degrees of lattice "softness" or permanent lattice defects rather than (static) structural distortions.

In case of $\left(\mathrm{C}_{7} \mathrm{H}_{7} \mathrm{~N}_{2}\right) \mathrm{PbI}_{3}$, we propose that the occurrence of the broad PL emission is based on its 1D lattice topology (see Figure 4) which assists the rapid formation of self-trapped excitons without potential barrier. ${ }^{[27,28]}$ We also assign the broad $\mathrm{PL}$ emission of $\left(\mathrm{C}_{7} \mathrm{H}_{7} \mathrm{~N}_{2}\right)_{2} \mathrm{PbCl}_{4}$ to the recombination of selftrapped excitons due to its broad emission profile with a FWHM of $190 \mathrm{~nm}$ and a large Stokes shift of over $100 \mathrm{~nm}$, which is typical for the emission of self-trapped excitons. ${ }^{[7,8,24]}$ Based on this broad emission profile and the additionally absorbing states below the bandgap, we propose that for $\left(\mathrm{C}_{7} \mathrm{H}_{7} \mathrm{~N}_{2}\right)_{2} \mathrm{PbCl}_{4}$ either facile electron-phonon coupling occurs or a small defect concentration must be present that cannot be resolved by PXRD measurements. In order to fully understand the different nature and origin of the emitting states in $\left(\mathrm{C}_{7} \mathrm{H}_{7} \mathrm{~N}_{2}\right)_{2} \mathrm{PbCl}_{4}$ compared to $\left(\mathrm{C}_{7} \mathrm{H}_{7} \mathrm{~N}_{2}\right)_{2} \mathrm{PbBr}_{4}$, further studies such as temperature dependent or time-resolved PL measurements are required. We also would like to note that a comparable impact of halide exchange from bromide to chloride on the optical properties has previously been observed in 2D hybrid perovskites by the appearance of inhomogeneous PL emission $^{[29]}$ or by increasing Stokes shifts and spectral emission widths for 3D perovskites of $\mathrm{MAPbBr}_{3-x} \mathrm{Cl}_{x}{ }^{[30]}$

\section{Conclusions}

The crystal structures of the compounds $\left(\mathrm{C}_{7} \mathrm{H}_{7} \mathrm{~N}_{2}\right)_{2} \mathrm{PbCl}_{4}$, $\left(\mathrm{C}_{7} \mathrm{H}_{7} \mathrm{~N}_{2}\right)_{2} \mathrm{PbBr}_{4}$, and $\left(\mathrm{C}_{7} \mathrm{H}_{7} \mathrm{~N}_{2}\right)_{2} \mathrm{PbI}_{4}$, a new series of closely related $2 \mathrm{D}$ hybrid perovskites, are reported for the first time and discussed with respect to interactions between the inorganic and organic sublattices. In addition, we confirmed the crystal structure of $\left(\mathrm{C}_{7} \mathrm{H}_{7} \mathrm{~N}_{2}\right) \mathrm{PbI}_{3}$, which has been obtained as phase-pure bulk material for the first time. ${ }^{[14]}$ Several lowtemperature routes for the synthesis of the benzimidazolium lead halides were shown to be feasible with excellent yields [except for $\left(\mathrm{C}_{7} \mathrm{H}_{7} \mathrm{~N}_{2}\right)_{2} \mathrm{PbI}_{4}$ ], including solvent-free mechanochemical reactions and in-situ protonation of benzimidazole using hydrohalic acids as a solvent. The local structure and stability of $\left(\mathrm{C}_{7} \mathrm{H}_{7} \mathrm{~N}_{2}\right)_{2} \mathrm{PbCl}_{4}, \quad\left(\mathrm{C}_{7} \mathrm{H}_{7} \mathrm{~N}_{2}\right)_{2} \mathrm{PbBr}_{4}$, and $\left(\mathrm{C}_{7} \mathrm{H}_{7} \mathrm{~N}_{2}\right) \mathrm{PbI}_{3}$ were studied with solid-state NMR spectroscopy and thermal analysis, respectively, revealing thermal stabilities up to $300{ }^{\circ} \mathrm{C}$ for the chloride and bromide and up to $350{ }^{\circ} \mathrm{C}$ for the iodide. Due to the close structural relationship between the 2:1 compounds, the decrease in bandgap from $\left(\mathrm{C}_{7} \mathrm{H}_{7} \mathrm{~N}_{2}\right)_{2} \mathrm{PbCl}_{4}$ to $\left(\mathrm{C}_{7} \mathrm{H}_{7} \mathrm{~N}_{2}\right)_{2} \mathrm{PbBr}_{4}$ to $\left(\mathrm{C}_{7} \mathrm{H}_{7} \mathrm{~N}_{2}\right)_{2} \mathrm{PbI}_{4}$ determined by optical absorption measurements can be ascribed to the choice of the halide, which is the only variable. The influence of dimensionality on the bandgap was demonstrated by comparing $E_{\mathrm{g}}$ for yellow $\left(\mathrm{C}_{7} \mathrm{H}_{7} \mathrm{~N}_{2}\right) \mathrm{PbI}_{3}$ featuring a $1 \mathrm{D}$ chainlike structure and for the $2 \mathrm{D}$ red compound $\left(\mathrm{C}_{7} \mathrm{H}_{7} \mathrm{~N}_{2}\right)_{2} \mathrm{PbI}_{4}$. $\mathrm{PL}$ measurements revealed a sharp $\mathrm{PL}$ emission for $\left(\mathrm{C}_{7} \mathrm{H}_{7} \mathrm{~N}_{2}\right)_{2} \mathrm{PbBr}_{4}$ and BzImPb4/3, whereas $\left(\mathrm{C}_{7} \mathrm{H}_{7} \mathrm{~N}_{2}\right)_{2} \mathrm{PbCl}_{4}$ and $\left(\mathrm{C}_{7} \mathrm{H}_{7} \mathrm{~N}_{2}\right) \mathrm{PbI}_{3}$ show a rather broad and unstructured PL emission. We suggest that the differences in PL emission can be traced back to a more efficient coupling of self-trapped excitons to phonons or lattice defects in the compounds featuring broad PL emission bands.

\section{Experimental Section}

Materials and Methods: $\mathrm{PbCl}_{2}$ (Sigma-Aldrich, 98\%), $\mathrm{PbBr}_{2}$ (Sigma-Aldrich, $\geq 98 \%$ ), $\mathrm{PbI}_{2}$ (Acros Organics, $99 \%$ ), benzimidazole (Alfa Aesar, 99\%), concentrated hydrochloric acid (Brenntag, purum), concentrated hydrobromic acid (Acros Organics, pure), concentrated hydriodic acid (Acros Organics, for analysis), ethyl acetate (Staub \& Co. Silbermann, 99.8\%), ether (Bernd Kraft, 95.5\%), and dimethylformamide (Alfa Aesar, 99\%) were commercially available and used as received without further purification.

Synthesis of $\left(\mathbf{C}_{7} \mathbf{H}_{7} \mathbf{N}_{\mathbf{2}}\right)_{2} \mathbf{P b C l}_{\mathbf{4}}$ : Benzimidazole $(47.7 \mathrm{mg}, 0.4 \mathrm{mmol})$, $\mathrm{PbCl}_{2}(56.8 \mathrm{mg}, 0.2 \mathrm{mmol})$, and $4 \mathrm{~mL} \mathrm{HCl}$ were heated to $80{ }^{\circ} \mathrm{C}$ for 2 $\mathrm{h}$, whereupon the solids were dissolved completely. The solvent was subsequently removed in a nitrogen flow, whereupon a white solid precipitated. Single crystals suitable for X-ray diffraction analysis were obtained by evaporating the solvent at room temperature instead. $\left(\mathrm{C}_{7} \mathrm{H}_{7} \mathrm{~N}_{2}\right)_{2} \mathrm{PbCl}_{4}$ : calcd. C 28.63; $\mathrm{H} 2.40 ; \mathrm{N} 9.54 ; \mathrm{Cl} 24.14 \%$; found: C 28.41; H 2.34; N 9.46; Cl 24.28\%. IR: $\tilde{v}=3146(\mathrm{~m}), 3096(\mathrm{~m})$, 3070 (m), 3038 (m), $3006(\mathrm{~m}), 2962$ (m), 2940 (m), $2854(\mathrm{~m}), 2814$ (m), 2748 (w), 1817 (w), $1623(\mathrm{w}), 1522(\mathrm{w}), 1496(\mathrm{w}), 1447$ (s), 1398 (w), 1370 (vs), 1282 (w), 1256 (s), 1235 (w), $1171(\mathrm{w}), 1160$ (w), 1140 (w), 1101 (w), 1003 (m), 944 (w), 910 (w), 882 (w), 773 (s), $742(\mathrm{vs}) \mathrm{cm}^{-1}$.

Synthesis of $\left(\mathbf{C}_{7} \mathbf{H}_{7} \mathbf{N}_{2}\right)_{2} \mathbf{P b B r}_{\mathbf{4}}$ : Benzimidazole $(47.7 \mathrm{mg}, 0.4 \mathrm{mmol})$, $\mathrm{PbBr}_{2}(74.9 \mathrm{mg}, 0.2 \mathrm{mmol})$ and $4 \mathrm{~mL} \mathrm{HBr}$ were heated to $80{ }^{\circ} \mathrm{C}$ for 2 $\mathrm{h}$, whereupon the solids were dissolved completely. The solvent was subsequently removed under nitrogen flow. The obtained yellow solid was washed with ethyl acetate. Single yellow crystals suitable for Xray diffraction analysis were obtained by evaporating the solvent at room temperature instead. $\left(\mathrm{C}_{7} \mathrm{H}_{7} \mathrm{~N}_{2}\right)_{2} \mathrm{PbBr}_{4}$ : calcd. $\mathrm{C} 21.98 ; \mathrm{H} \mathrm{1.84;} \mathrm{N}$ 7.32; $\mathrm{Br} 41.77 \%$; found: C 21,95; H 1.86; N 7.32; Br 40.44\%. IR: $\tilde{v}$ $=3140(\mathrm{~m}), 3103(\mathrm{~m}), 3077(\mathrm{~m}), 3009(\mathrm{~m}), 2971(\mathrm{~m}), 2846(\mathrm{~m}), 2810$ (w), 1792 (w), 1619 (m), 1524 (w), 1496 (w), 1446 (s), 1397 (w), 1365 (vs), 1346 (m), 1277 (w), 1255 (vs), 1170 (w), 1158 (w), 1133

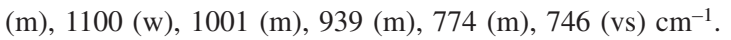

Additionally, $\left(\mathrm{C}_{7} \mathrm{H}_{7} \mathrm{~N}_{2}\right)_{2} \mathrm{PbBr}_{4}$ can be obtained by heating benzimidazole $(179 \mathrm{mg}, 1.5 \mathrm{mmol}), \mathrm{PbBr}_{2}(281 \mathrm{mg}, 0.75 \mathrm{mmol})$ and $15 \mathrm{~mL}$ $\mathrm{HBr}$ to $80^{\circ} \mathrm{C}$ for $2 \mathrm{~h}$. The product was obtained by adding ethyl acetate to the reaction mixture after it was cooled down to room temperature.

Synthesis of $\left(\mathbf{C}_{7} \mathbf{H}_{7} \mathbf{N}_{2}\right) \mathbf{P b I}_{3}$ : Benzimidazole $(89.5 \mathrm{mg}, 0.75 \mathrm{mmol})$, $\mathrm{PbI}_{2}$ (349 $\mathrm{mg}, 0.75 \mathrm{mmol}$ ), and $15 \mathrm{~mL}$ HI were heated to $80^{\circ} \mathrm{C}$ for 2 h. A clear solution could not be obtained at any time. After cooling the reaction mixture down to room temperature dissolved product was precipitated by adding ethyl acetate. Afterwards, the yellow solid was filtered and washed with ethyl acetate. $\left(\mathrm{C}_{7} \mathrm{H}_{7} \mathrm{~N}_{2}\right) \mathrm{PbI}_{3}$ : calcd. C 11.89; H 1.00; N 3.96; I 53.84\%; found: C 11.92; H 1.04; N 4.01; I $51.83 \%$. IR: $\tilde{v}=3254(\mathrm{~m}), 3227(\mathrm{~m}), 3133(\mathrm{~m}), 1612(\mathrm{~m}), 1522(\mathrm{w}), 1485(\mathrm{~m})$, 1444 (s), 1421 (w), 1366 (s), 1346 (w), 1258 (m), 1206 (m), 1176 (w), 
1155 (m), 1134 (s), 1103 (s), 1003 (w), 939 (w), 923 (s), 887 (w), 879 (w), 850 (w), 773 (w), 750 (vs), 687 (vs) $\mathrm{cm}^{-1}$.

$\left(\mathrm{C}_{7} \mathrm{H}_{7} \mathrm{~N}_{2}\right) \mathrm{PbI}_{3}$ was also synthesized by heating benzimidazole (23.9 mg, $0.2 \mathrm{mmol}$ ), $\mathrm{PbI}_{2}\left(93.1 \mathrm{mg}, 0.2 \mathrm{mmol}\right.$ ) and $4 \mathrm{~mL} \mathrm{HI}$ to $80^{\circ} \mathrm{C}$ for $2 \mathrm{~h}$. A yellow solid was gained by evaporating the solvent in a nitrogen flow after the reaction mixture was cooled down to room temperature. Subsequently, the product was washed with ethyl acetate. Single yellow crystals suitable for X-ray diffraction analysis were obtained by evaporating the solvent at room temperature instead.

Solvent-free Synthesis of $\left(\mathrm{C}_{7} \mathrm{H}_{7} \mathrm{~N}_{2}\right)_{2} \mathrm{PbBr}_{4}$ and $\left(\mathrm{C}_{7} \mathrm{H}_{7} \mathrm{~N}_{2}\right) \mathrm{PbI}_{3}$ : Benzimidazole $(51.1 \mathrm{mg}, 0.43 \mathrm{mmol})$ and $\mathrm{PbBr}_{2}(80 \mathrm{mg}, 0.21 \mathrm{mmol})$ were mixed and ground with a few drops of $\mathrm{HBr}$. Subsequently, the powder was washed by adding a little ethyl acetate, grinding the mixture and removing the ethyl acetate afterwards. This procedure was repeated a couple of times. In a last step the solvent was removed in a nitrogen flow. The same experimental procedure was performed to synthesize $\left(\mathrm{C}_{7} \mathrm{H}_{7} \mathrm{~N}_{2}\right) \mathrm{PbI}_{3}$. Here, benzimidazole $(25.7 \mathrm{mg}, 0.21 \mathrm{mmol})$, $\mathrm{PbI}_{2}(100 \mathrm{mg}, 0.22 \mathrm{mmol})$, and a few drops of $\mathrm{HI}$ were mixed and ground.

Synthesis of $\left(\mathbf{C}_{7} \mathbf{H}_{7} \mathbf{N}_{2}\right) \mathbf{I} \cdot \mathbf{H}_{2} \mathbf{O}$ : $\mathrm{HI}(0.6 \mathrm{~mL})$ was added to benzimidazole $(200 \mathrm{mg}, 1.68 \mathrm{mmol}$ ), while cooling with an ice bath. Subsequently, the solvent was evaporated in a nitrogen flow. The product was washed with ethyl acetate and ether. $\left(\mathrm{C}_{7} \mathrm{H}_{7} \mathrm{~N}_{2}\right) \mathrm{I} \cdot \mathrm{H}_{2} \mathrm{O}$ : calcd. C 31.84; H 3.44; N 10.61\%; found: C 31.80; H 3.47; N $10.62 \%$. IR: $\tilde{v}$ $=3468(\mathrm{w}), 3403(\mathrm{~m}), 3154(\mathrm{w}), 3123(\mathrm{~m}), 3099(\mathrm{~m}), 3064(\mathrm{~m}), 3036$ (m), 3008 (m), 2970 (m), $2929(\mathrm{~m}), 2844(\mathrm{~m}), 2812(\mathrm{~m}), 2751(\mathrm{~m})$, 1607 (m), 1520 (w), 1494 (w), 1442 (s), 1372 (s), 1349 (m), 1258 (s), 1232 (m), 1178 (w), 1161 (w), 1145 (w), 1124 (w), 1100 (w), 1005 (w), 934 (m), 878 (m), 852 (s), 772 (s), 762 (s), 740 (vs) $\mathrm{cm}^{-1} .{ }^{1} \mathbf{H}$ NMR ([D $]$ DMSO, $\left.20^{\circ} \mathrm{C}\right): \delta=9.57\left(\mathrm{~s}, 1 \mathrm{H},-\mathrm{C}_{2}-\mathrm{H}\right), 7.87\left(\mathrm{~d}_{\mathrm{d}}, 2 \mathrm{H}\right.$, $\left.\mathrm{C}_{4 / 7}-\mathrm{H}\right) 7.60\left(\mathrm{~d}_{\mathrm{d}}, 2 \mathrm{H}, \mathrm{C}_{5 / 6}-\mathrm{H}\right) .{ }^{13} \mathrm{C}$ NMR ([D $]$ DMSO, $\left.20^{\circ} \mathrm{C}\right): \delta=$ $140.68\left(\mathrm{~s}, \mathrm{C}_{2}\right), 130.50\left(\mathrm{~s}, \mathrm{C}_{8 / 9}\right), 126.12\left(\mathrm{~s}, \mathrm{C}_{5 / 6}\right), 114.47\left(\mathrm{~s}, \mathrm{C}_{4 / 7}\right) \mathrm{ppm}$.

Synthesis of $\left(\mathrm{C}_{7} \mathbf{H}_{7} \mathbf{N}_{2}\right)_{2} \mathbf{P b I}_{4}$ : Single crystals suitable for X-ray diffraction analysis were obtained by dissolving $\left(\mathrm{C}_{7} \mathrm{H}_{7} \mathrm{~N}_{2}\right) \mathrm{I} \cdot \mathrm{H}_{2} \mathrm{O}(20 \mathrm{mg}$, $0.076 \mathrm{mmol})$ and $\mathrm{PbI}_{2}(9.5 \mathrm{mg}, 0.02 \mathrm{mmol})$ in $0.3 \mathrm{~mL} \mathrm{DMF}$ at room temperature and subsequently, evaporating the solvent at room temperature. Attempting to synthesize $\left(\mathrm{C}_{7} \mathrm{H}_{7} \mathrm{~N}_{2}\right)_{2} \mathrm{PbI}_{4}$ as a bulk material $\left(\mathrm{C}_{7} \mathrm{H}_{7} \mathrm{~N}_{2}\right) \mathrm{PbI}_{3}(212 \mathrm{mg}, 0.3 \mathrm{mmol})$ was mixed with $\left(\mathrm{C}_{7} \mathrm{H}_{7} \mathrm{~N}_{2}\right) \cdot \mathrm{I}_{2} \mathrm{O}$ (73.6 mg, $0.28 \mathrm{mmol}$ ) and ground for $5 \mathrm{~d}$ with a Specamill vibratory ball mill (Specac). A red powder was obtained.

Single-cyrstal $\mathrm{X}$-ray diffraction: Single-crystal $\mathrm{X}$-ray diffraction data of $\left(\mathrm{C}_{7} \mathrm{H}_{7} \mathrm{~N}_{2}\right)_{2} \mathrm{PbCl}_{4}$ and $\left(\mathrm{C}_{7} \mathrm{H}_{7} \mathrm{~N}_{2}\right)_{2} \mathrm{PbI}_{4}$ were collected with a Bruker D8 Venture diffractometer equipped with a rotating anode generator with Mo- $K_{\alpha}$ radiation $(\lambda=0.71073 \AA)$ at $100 \mathrm{~K}$. Both compounds crystallized as two-component twins, hence TWINABS was applied for data reduction and absorption correction. ${ }^{[31]}$ The reflection data were merged in Laue class $2 / \mathrm{m}\left[R_{\text {int }}=0.0367\left(\left(\mathrm{C}_{7} \mathrm{H}_{7} \mathrm{~N}_{2}\right)_{2} \mathrm{PbCl}_{4}\right), R_{\text {int }}=\right.$ $\left.0.0430\left(\left(\mathrm{C}_{7} \mathrm{H}_{7} \mathrm{~N}_{2}\right)_{2} \mathrm{PbI}_{4}\right)\right]$. A D8 Quest I $\mu \mathrm{S}$ diffractometer with a MoMicrosource generator was used to collect single-crystal X-ray diffraction data of $\left(\mathrm{C}_{7} \mathrm{H}_{7} \mathrm{~N}_{2}\right)_{2} \mathrm{PbBr}_{4}$ and $\left(\mathrm{C}_{7} \mathrm{H}_{7} \mathrm{~N}_{2}\right) \mathrm{PbI}_{3}$ at $173 \mathrm{~K}$. The diffraction intensities were integrated using the SAINT software package ${ }^{[32]}$ and a multi-scan absorption correction was applied with SADABS. ${ }^{[33]}$ The crystal structure was solved by direct methods (SIR97) ${ }^{[34]}$ and refined against $F^{2}$ by applying the full-matrix least-squares method (SHELXL-2014/7). ${ }^{[35]}$ Only for $\left(\mathrm{C}_{7} \mathrm{H}_{7} \mathrm{~N}_{2}\right)_{2} \mathrm{PbI}_{4}$ the program SHELXT2014 was used for the structure solution. ${ }^{[36]}$ Hydrogen positions were calculated according to geometrical criteria and treated as riding on their parent atoms with the exception of the N-bound hydrogen positions in $\left(\mathrm{C}_{7} \mathrm{H}_{7} \mathrm{~N}_{2}\right) \mathrm{PbI}_{3}$, which were refined with a restrained $\mathrm{N}-\mathrm{H}$ bond distance of $0.88(1) \AA$ A Their atomic displacement parameters were constraint to 1.2 times the value of their parent atom. All non-hydrogen atoms were refined anisotropically.

Crystallographic data (excluding structure factors) for the structures in this paper have been deposited with the Cambridge Crystallographic Data Centre, CCDC, 12 Union Road, Cambridge CB21EZ, UK. Copies of the data can be obtained free of charge on quoting the depository numbers CCDC-1507154, CCDC-1507155, CCDC1507156 and CCDC-1507157 (Fax: +44-1223-336-033; E-Mail: deposit@ccdc.cam.ac.uk, http://www.ccdc.cam.ac.uk).

Powder X-ray Diffraction (PXRD): Powder X-ray diffraction patterns were collected with STOE Stadi P diffractometers in a modified Debye-Scherrer set-up equipped with a Mythen1K detector using $\mathrm{Ge}(111)$-monochromated $\mathrm{Cu}-K_{\alpha 1}$ radiation $(\lambda=1.54059 \AA)$. Samples were encapsulated into capillaries under ambient conditions prior to the measurement. Rietveld refinements were performed using TOPAS academic. $^{[37]}$

Infrared (IR) Spectroscopy: FT-IR spectra were recorded at ambient conditions between 650 and $4000 \mathrm{~cm}^{-1}$ on a Spektrum BX II FTIR spectrometer (Perkin-Elmer) equipped with a DuraSampler diamond ATR device.

Absorption and Photoluminescence (PL) Measurements: For optical measurements, samples were clamped between two quartz substrates. Absorption spectra were measured with an Agilent Technologies $8453 \mathrm{UV} / \mathrm{Vis}$ spectrometer in an integrating sphere. Steady-state photoluminescence measurements were recorded with a PicoQuant FluoTime 300 fluorescence spectrometer, using a $300 \mathrm{~W}$ xenon arc lamp as excitation source. All measurements were done in air under ambient conditions.

Solid-state NMR Spectroscopy: ${ }^{1} \mathrm{H},{ }^{13} \mathrm{C}$ and ${ }^{15} \mathrm{~N}$ MAS solid-state NMR spectra were recorded with a Bruker Avance III-500 $\left(H_{0}=11.74\right.$ T) spectrometer at room temperature using a $4 \mathrm{~mm}$ probe, with the sample spinning at $10 \mathrm{kHz}$. All spectra were referenced to $0.1 \%$ $\mathrm{Si}\left(\mathrm{CH}_{3}\right)_{4}(\delta=0.0 \mathrm{ppm})$ in $\mathrm{CDCl}_{3}$. ${ }^{1} \mathrm{H}$ spectra were obtained in one scan. ${ }^{13} \mathrm{C}$ cross-polarization (CP) MAS spectra were recorded with a contact time of $3 \mathrm{~ms}$ in 496,1024, and 136 scans for $\left(\mathrm{C}_{7} \mathrm{H}_{7} \mathrm{~N}_{2}\right)_{2} \mathrm{PbCl}_{4}$, $\left(\mathrm{C}_{7} \mathrm{H}_{7} \mathrm{~N}_{2}\right)_{2} \mathrm{PbBr}_{4}$ and $\left(\mathrm{C}_{7} \mathrm{H}_{7} \mathrm{~N}_{2}\right) \mathrm{PbI}_{3}$, respectively. The repetition time was set to $128 \mathrm{~s}$ for $\left(\mathrm{C}_{7} \mathrm{H}_{7} \mathrm{~N}_{2}\right)_{2} \mathrm{PbCl}_{4}$ and to $64 \mathrm{~s}$ for $\left(\mathrm{C}_{7} \mathrm{H}_{7} \mathrm{~N}_{2}\right)_{2} \mathrm{PbBr}_{4}$ and $\left(\mathrm{C}_{7} \mathrm{H}_{7} \mathrm{~N}_{2}\right) \mathrm{PbI}_{3} .{ }^{15} \mathrm{~N} \mathrm{CP}$ MAS spectra were acquired with a contact time of $1 \mathrm{~ms}$ and a recycle delay of $64 \mathrm{~s}$ in 2752, 4104 and 1344 scans for $\left(\mathrm{C}_{7} \mathrm{H}_{7} \mathrm{~N}_{2}\right)_{2} \mathrm{PbCl}_{4},\left(\mathrm{C}_{7} \mathrm{H}_{7} \mathrm{~N}_{2}\right)_{2} \mathrm{PbBr}_{4}$, and $\left(\mathrm{C}_{7} \mathrm{H}_{7} \mathrm{~N}_{2}\right) \mathrm{PbI}_{3}$, respectively. All ${ }^{13} \mathrm{C}$ and ${ }^{15} \mathrm{~N}$ spectra were recorded with proton decoupling using the TPPM method. ${ }^{[38]}$

Solution-state NMR Spectroscopy: ${ }^{1} \mathrm{H}$ and ${ }^{13} \mathrm{C}$ NMR spectra were recorded with a Bruker 400 TR spectrometer in $\left[\mathrm{D}_{6}\right] \mathrm{DMSO}$ at room temperature.

Energy Dispersive X-ray Spectroscopy (EDX): A FEI Helios G3 UC scanning electron microscope (SEM) operating at $20 \mathrm{kV}$ was used to determine the content of $\mathrm{Pb}$ and $\mathrm{Br}$ in $\left(\mathrm{C}_{7} \mathrm{H}_{7} \mathrm{~N}_{2}\right)_{2} \mathrm{PbBr}_{4}$ locally.

Thermal Analysis: DTA and TG data were collected simultaneously with a NETZSCH STA 409C/CD thermoanalyzer. Samples were heated in an argon flow of $100 \mathrm{~mL} \cdot \mathrm{min}^{-1}$ in aluminium oxide crucibles from room temperature to $800{ }^{\circ} \mathrm{C}$ for $\left(\mathrm{C}_{7} \mathrm{H}_{7} \mathrm{~N}_{2}\right)_{2} \mathrm{PbCl}_{4}$ and to $900{ }^{\circ} \mathrm{C}$ for $\left(\mathrm{C}_{7} \mathrm{H}_{7} \mathrm{~N}_{2}\right)_{2} \mathrm{PbBr}_{4}$ and $\left(\mathrm{C}_{7} \mathrm{H}_{7} \mathrm{~N}_{2}\right) \mathrm{PbI}_{3}$ with a heating rate of $10 \mathrm{~K} \cdot \mathrm{min}^{-1}$.

Elemental Analysis: The elemental analyzer systems Vario EL and Vario Micro (Elementar Analysensysteme $\mathrm{GmbH}$ ) were used to deter- 
mine the content of $\mathrm{C}, \mathrm{H}$, and $\mathrm{N}$. The percentage of $\mathrm{Cl}, \mathrm{Br}$ and I was analysed with the titrator 888 Titrando (Metrohm).

Supporting Information (see footnote on the first page of this article): Crystallographic data of $\left(\mathrm{C}_{7} \mathrm{H}_{7} \mathrm{~N}_{2}\right)_{2} \mathrm{PbCl}_{4},\left(\mathrm{C}_{7} \mathrm{H}_{7} \mathrm{~N}_{2}\right)_{2} \mathrm{PbBr}_{4}$, $\left(\mathrm{C}_{7} \mathrm{H}_{7} \mathrm{~N}_{2}\right)_{2} \mathrm{PbI}_{4}$ and $\left(\mathrm{C}_{7} \mathrm{H}_{7} \mathrm{~N}_{2}\right) \mathrm{PbI}_{3}$. Rietveld refinement results for all discussed PXRD data. Photograph of BzImPbI4/3 powder. EDX analysis data and SEM image of $\left(\mathrm{C}_{7} \mathrm{H}_{7} \mathrm{~N}_{2}\right)_{2} \mathrm{PbBr}_{4}$ obtained by a mechanochemical reaction. Assignment of chemical shifts obtained by solid-state NMR spectroscopy. Tauc plots of $\left(\mathrm{C}_{7} \mathrm{H}_{7} \mathrm{~N}_{2}\right)_{2} \mathrm{PbCl}_{4}$, $\left(\mathrm{C}_{7} \mathrm{H}_{7} \mathrm{~N}_{2}\right)_{2} \mathrm{PbBr}_{4},\left(\mathrm{C}_{7} \mathrm{H}_{7} \mathrm{~N}_{2}\right)_{2} \mathrm{PbI}_{3}$ and (BzImPbI4/3). Thermal analysis data for $\left(\mathrm{C}_{7} \mathrm{H}_{7} \mathrm{~N}_{2}\right)_{2} \mathrm{PbCl}_{4},\left(\mathrm{C}_{7} \mathrm{H}_{7} \mathrm{~N}_{2}\right)_{2} \mathrm{PbBr}_{4}$ and $\left(\mathrm{C}_{7} \mathrm{H}_{7} \mathrm{~N}_{2}\right) \mathrm{PbI}_{3}$.

\section{Acknowledgements}

We gratefully acknowledge financial support by the Max Planck Gesellschaft, Deutsche Telekom Stiftung (scholarship for $C L$ ), Carl Zeiss Stiftung (scholarship for STB), the cluster of excellence Nanosystems Initiative Munich (NIM) and the Center for NanoScience (CeNS). Thanks to Christian Minke (Schnick group, LMU Munich) for performing the solid state NMR spectroscopy measurements and to Daniel Weber, M.Sc. and Willi Hölle for collecting the thermal analysis data. We also thank Viola Duppel, Dr. Sophia Betzler and Dr. Ramona Hoffmann (Bein group, LMU Munich) for performing the EDX measurements. Thanks to Christine Stefani (Dinnebier group, MPI-FKF) for collecting additional PXRD data.

\section{References}

[1] E. A. Muljarov, S. G. Tikhodeev, N. A. Gippius, T. Ishihara, Phys. Rev. B 1995, 51, 14370-14378.

[2] G. A. Mousdis, G. C. Papavassiliou, C. P. Raptopoulou, A. Terzis, J. Mater. Chem. 2000, 10, 515-518.

[3] T. Ishihara, J. Takahashi, T. Goto, Solid State Commun. 1989, 69, 933-936.

[4] M. Era, S. Morimoto, T. Tsutsui, S. Saito, Appl. Phys. Lett. 1994, 65, 676-678.

[5] K. Chondroudis, D. B. Mitzi, Chem. Mater. 1999, 11, 3028-3030.

[6] X. Hong, T. Ishihara, A. V. Nurmikko, Phys. Rev. B 1992, 45, 6961-6964.

[7] E. R. Dohner, E. T. Hoke, H. I. Karunadasa, J. Am. Chem. Soc. 2014, 136, 1718-1721.

[8] E. R. Dohner, A. Jaffe, L. R. Bradshaw, H. I. Karunadasa, J. Am. Chem. Soc. 2014, 136, 13154-13157.

[9] Q. Chen, N. De Marco, Y. Yang, T.-B. Song, C.-C. Chen, H. Zhao, Z. Hong, H. Zhou, Y. Yang, Nano Today 2015, 10, 355-396.

[10] D. B. Mitzi, in Progress in Inorganic Chemistry, John Wiley \& Sons, Inc., 1999, pp. 1-121.

[11] S. D. Stranks, G. E. Eperon, G. Grancini, C. Menelaou, M. J. P. Alcocer, T. Leijtens, L. M. Herz, A. Petrozza, H. J. Snaith, Science 2013, 342, 341-344.
[12] D. Solis-Ibarra, H. I. Karunadasa, Angew. Chem. Int. Ed. 2014, 53, 1039-1042.

[13] D. Solis-Ibarra, I. C. Smith, H. I. Karunadasa, Chem. Sci. 2015, 6, 4054-4059.

[14] G.-E. Wang, M.-S. Wang, X.-M. Jiang, G.-N. Liu, L.-Z. Cai, G.C. Guo, J.-S. Huang, Sci. Sin. Chim. 2011, 41, 717-725.

[15] N. S. Biradar, N. N. Sirmokadam, J. Inorg. Nucl. Chem. 1973, 35, 3639-3641.

[16] D. B. Mitzi, Chem. Mater. 1996, 8, 791-800.

[17] R. J. Pugmire, D. M. Grant, J. Am. Chem. Soc. 1971, 93, 18801887.

[18] C. I. Nieto, P. Cabildo, M. Á. García, R. M. Claramunt, I. Alkorta, J. Elguero, Beilstein J. Org. Chem. 2014, 10, 1620-1629.

[19] S. A. Kulkarni, T. Baikie, P. P. Boix, N. Yantara, N. Mathews, S. Mhaisalkar, J. Mater. Chem. A 2014, 2, 9221-9225.

[20] J. H. Noh, S. H. Im, J. H. Heo, T. N. Mandal, S. I. Seok, Nano Lett. 2013, 13, 1764-1769.

[21] G. E. Eperon, S. D. Stranks, C. Menelaou, M. B. Johnston, L. M. Herz, H. J. Snaith, Energy Environ. Sci. 2014, 7, 982-988.

[22] I. C. Smith, E. T. Hoke, D. Solis-Ibarra, M. D. McGehee, H. I. Karunadasa, Angew. Chem. 2014, 126, 11414-11417.

[23] G. Maculan, A. D. Sheikh, A. L. Abdelhady, M. I. Saidaminov, M. A. Haque, B. Murali, E. Alarousu, O. F. Mohammed, T. Wu, O. M. Bakr, J. Phys. Chem. Lett. 2015, 6, 3781-3786.

[24] T. Hu, M. D. Smith, E. R. Dohner, M.-J. Sher, X. Wu, M. T. Trinh, A. Fisher, J. Corbett, X. Y. Zhu, H. I. Karunadasa, A. M. Lindenberg, J. Phys. Chem. Lett. 2016, 7, 2258-2263.

[25] C. Lermer, S. T. Birkhold, I. L. Moudrakovski, P. Mayer, L. M. Schoop, L. Schmidt-Mende, B. V. Lotsch, Chem. Mater. 2016, 28, 6560-6566.

[26] A. Yangui, D. Garrot, J. S. Lauret, A. Lusson, G. Bouchez, E. Deleporte, S. Pillet, E. E. Bendeif, M. Castro, S. Triki, Y. Abid, K. Boukheddaden, J. Phys. Chem. C 2015, 119, 23638-23647.

[27] V. V. Kabanov, O. Y. Mashtakov, Phys. Rev. B 1993, 47, 60606064.

[28] D. Emin, T. Holstein, Phys. Rev. Lett. 1976, 36, 323-326.

[29] L. Dou, A. B. Wong, Y. Yu, M. Lai, N. Kornienko, S. W. Eaton, A. Fu, C. G. Bischak, J. Ma, T. Ding, N. S. Ginsberg, L.-W. Wang, A. P. Alivisatos, P. Yang, Science 2015, 349, 1518-1521.

[30] R. Comin, G. Walters, E. S. Thibau, O. Voznyy, Z.-H. Lu, E. H. Sargent, J. Mater. Chem. C 2015, 3, 8839-8843.

[31] TWINABS, Bruker, Madison, Wisconsin, USA, 2001.

[32] SAINT, Bruker, Madison, Wisconsin, USA, 2012.

[33] SADABS, Bruker, Madison, Wisconsin, USA, 2001.

[34] A. Altomare, M. C. Burla, M. Camalli, G. L. Cascarano, C. Giacovazzo, A. Guagliardi, A. G. G. Moliterni, G. Polidori, R. Spagna, J. Appl. Crystallogr. 1999, 32, 115-119.

[35] G. M. Sheldrick, Acta Crystallogr., Sect. C 2015, 71, 3-8.

[36] G. Sheldrick, Acta Crystallogr., Sect. A 2015, 71, 3-8.

[37] Topas Academic, version 5; Coelho Software: Brisbane, Australia, 2007.

[38] A. E. Bennett, C. M. Rienstra, M. Auger, K. V. Lakshmi, R. G. Griffin, J. Chem. Phys. 1995, 103, 6951-6958. 